\title{
Comparative Efficiency of Different Post-Emergence Herbicides for Controlling Broadleaved Weeds in Rain-fed Wheat
}

\author{
Zubina Hameed ${ }^{1}$, Muhammad Azim Malik ${ }^{1}$, Safdar Ali ${ }^{1 *}$, Muhammad Ansar ${ }^{1}$, Farina Shaheen ${ }^{1}$, Ijaz Ah- \\ $\operatorname{mad}^{2}$ and Khisrao Kalim ${ }^{3}$
}

${ }^{1}$ Department of Agronomy, Pir Mehr Ali Shah, Arid Agriculture University, Rawalpindi, Pakistan; ${ }^{2}$ Ecotoxicology Research Institute, National Agricultural Research Centre Islamabad, Pakistan; ${ }^{3}$ Livestock and Dairy Development Department, Peshawar, Khyber Pakbtunkbwa, Pakistan.

Abstract | Weeds are the major problem of rainfed wheat of Pothwar Region of Pakistan. Due to subsistence kind of farming and dependence on rainfall, people are reluctant to do expenses on chemical control of weeds in wheat. Similarly, due to lack of awareness, they use wheat weeds as animal fodder and the hand weeding affects crop stand and its tillering which ultimately reduces the wheat yield of the pothwar region. So, chemical control of weeds was hypothesized to be the best solution for winter weeds of rainfed wheat's weeds and for this purpose, a field study was carried out from October, 2010 to April, 2011 at University Research Farm Pir Mehr Ali Shah-Arid Agriculture University, Rawalpindi, Pakistan to evaluate the relative efficacy of different post-emergence herbicides viz. Clean wave $15 \mathrm{EO}$ (Aminopyralid + fluroxypyre) @ $0.8 \mathrm{~L} \mathrm{ha}^{-1}$, Aim $40 \mathrm{DF}$ (Carfentrazone ethyl)@0.05 Kg ha ${ }^{-1}$, Buctril-super $60 \mathrm{EC}$ (Bromoxynil + MCPA)@ $0.750 \mathrm{~L} \mathrm{ha}^{-1}$, Atlantis 3.6 WG (Mesosulfuron + iodosulfuron) @ $0.7 \mathrm{Kg} \mathrm{ha}^{-1}$, Sectril-M $40 \mathrm{EC}$ (Bromoxynil + MCPA) @ 1.2 L ha $^{-1}$, Brominal-M 40 EC (Bromoxynil + MCPA) @ $2.0 \mathrm{Kg} \mathrm{ha}^{-1}$ for controlling weeds in rainfed wheat. The experiment was laid out in Randomized Complete Block Design (RCBD) under split plot arrangement with three replications of each treatment. The wheat variety "Chakwal-50" was sown with a tractor-drawn rabi drill in the last week of October 2010 with a seeding rate of $125 \mathrm{~kg} \mathrm{ha}^{-1}$. The most dominant weeds found in the wheat crop were Fumaria indica, Convolvulus arvensis, Chenopodium album, and Asphodelus tenuifolius. The results of field experiment clearly showed that weed control efficiency was highest (98.18\%) in Buctril-super followed by Brominal-M (98.11\%) and hand weeded weed-free plots (100\%) as compared with other herbicides. Similarly Brominal-M and Buctril-super showed higher mortality percentage of weeds after weeds free (hand weeded) plots having (63.61\%), (62.64 \%) and (100\%) mortality percentages respectively. The plots treated with Buctril-super, Clean wave, Brominal-M, Sectril-M and hand weeding produced a higher number of tillers, plant height, spike length, and biological yield when compared with other treatments. The highest biological yield $\left(10.55 \mathrm{t} . \mathrm{ha}^{-1}\right)$ and grain yield $\left(3.57 \mathrm{t.} \mathrm{ha}^{-1}\right)$ were recorded in plots treated with Buctril-super along with highest benefit-cost ratio (2.52). Therefore, Buctril-super is recommended for best control of broad-leaved weeds and taking an economical yield of wheat.

Received | February 10, 2018; Accepted | November 01, 2018; Published | December 13, 2018

*Correspondence | Safdar Ali, Department of Agronomy, Pir Mehr Ali Shah, Arid Agriculture University, Rawalpindi, Pakistan; Email: safdaraliarid@yahoo.com

Citation | Hameed, Z., M. A. Malik., S. Ali, M. Ansar, F. Shaheen, I. Ahmad and K. Kalim. 2019. Comparative efficiency of different postemergence herbicides for controlling broadleaved weeds in rain-fed wheat. Pakistan Journal of Agricultural Research, 32(1): 78-86.

DOI | http://dx.doi.org/10.17582/journal.pjar/2019/32.1.78.86

Keywords | Comparative efficiency, Post-emergence herbicides, Broadleaved weeds, Buctril super, Rain-fed wheat yield 
Introduction

$\mathrm{W}$

Theat (Triticum aestivum L.) is one of the most important staple food cereals in Pakistan and the leading grain crop, feeding 1.5 million peo 'ple. Total cropped area of the country is $23.80 \mathrm{~m}$ ha, out of which $17.58 \mathrm{~m}$ ha is irrigated, and $3.96 \mathrm{~m}$ ha is rainfed. Wheat crop is grown on areas of 9.06 million ha with a total annual production of about 25 million tons, with an average yield of approximately $2.83 \mathrm{t}$ $\mathrm{ha}^{-1}$. However, in rain-fed conditions, the total cultivated area of the wheat crop is around 1.24 million ha with the crop yield of 2.00 million tons and the average yield of almost $1.53 \mathrm{t} \mathrm{ha}^{-1}$ (GOP, 2010). Wheat is used for making chapatti, bread, biscuit, cakes, pasta, noodles, etc. Wheat straw is used to feed livestock, making chipboard, poultry bedding and mixed with mud to spread on the roofs of the houses, etc. Despite the combined efforts of scientific and farming community, the potential yield, i.e. $\left(6 \mathrm{tha}^{-1}\right)$ could not be achieved still. The gap between the actual and potential yield of wheat is due to many factors like an infestation of insects, diseases, and weeds. Annual losses caused by weeds in Pakistan are higher than caused by plant diseases (Haq, 1970). Agricultural experts have assessed that weeds caused 17-25 percent annual losses in wheat (Shahid, 1994). Later on, estimated losses due to weeds were increased from 18-30 percent (Ashiq and Cheema, 2005). Weed infestation is a serious problem affecting the yield of wheat. The statistical range of wheat yield reduction in Pakistan caused by weeds is about 20-30\% (Abbas et al., 2009). Weeds are the principal barrier in the production of wheat as they decrease the crop productivity by competing for space, solar radiation soil moisture, nutrients, light, and $\mathrm{CO}_{2}$ (Zimdahl, 1980). Mostly weeds are hard and resistant to climatic extremes and are more efficient in utilization of competition components than crop plants, so crop growth and yield are adversely affected by the presence of weeds (Khalil et al., 2008). They exude all elopathic chemicals in the soil; provide environments for disease-causing agents along with the allocation of substitute host for several insects; and increase the cost of harvesting (Bekelle, 2004).

Weeds are responsible for declining crop yield, not only through competing for essential limiting factors of plant growth and development but also through the release of certain allelochemicals from the root system and other parts of plants into the root zone of desired crop plants. Herbicides successfully control weeds and improve the grain yield of crops (Akbar et al., 2011; Jabran et al., 2008; Razzaq et al., 2010). In the cropping system, it is a very effective method of weed control as it minimizes the crop productivity losses due to weed invasion and reduces the subsequent infestation of weeds at low and persistent levels. Weed management is a decision-making process based on the basic principles of science that bring together the information of climate, weed lifespan i.e. seeds, newly emerged plant, vegetative growth stages, flowering and seed set, and their relationship to the environment and all accessible approaches for weed management by the most cost-effective and environmentally sustainable ways. Weed seeds contaminate the crop seeds and increase the harvesting cost (Rao, 1983). Thus weeds decrease the yield, quality and market value of crop seeds (Ashiq et al., 2007).

Weed management practices in rainfed areas include manual as well as chemical weed control methods. Chemical weed control is preferred because of less labor investment and no mechanical damage to the crop that happens during manual weeding. The literature reviewed on the subject indicated that the chemical method to control weeds had been found comparatively efficient and economical (Majid and Hussain, 1983). Chemical weed control is efficient in producing higher grain yield even than hand weeding (Ahmad et al., 1993). For obtaining best results, chemical control of weeds emphasis should be on the best choice for herbicide selection, environment and effective dose of herbicide as the non-judicious use of herbicides can reduce the crop productivity instead of improving yield (Faryad et al., 1998).

Different herbicide companies claim for effective post-emergence weed control in wheat by their products, and a lot of work has been done in this regard. The results of the previous studies showed that affinity and topik performed better compared to other post-emergence herbicides (Bibi et al., 2008). Khali1 et al. (2008) too found a better performance of affinity against broad-leaved weeds in wheat. It was also found that buctril-super $60 \%$ and starane-M provided effective control of broadleaved weeds in wheat (Abbas et al., 2009). Farmers of rainfed areas are facing crop failure due to uncertain weather conditions, and they are not sure for economic productivity of wheat crop that is why they are reluctant to use herbicides for controlling weeds in wheat. Keeping in view the importance of wheat and weed associated prob- 
lems in changing the environment as well as market situations this study might be considered an essential component of weed management. The need of time is to check the relative effectiveness of newly introduced post-emergence herbicidal chemistry for the guidance of farming community. Keeping all these factors in view the objectives of this study were to compare and evaluate the relative efficacy of post-emergence herbicidal chemistry against broad-leaved weeds suppression and to evaluate the growth and establishment of the wheat crop under rainfed conditions.

\section{Materials and Methods}

\section{Sowing time and location}

The land was prepared by two ploughing with cultivator followed by planking. The experiment was carried out from October 2010 to April 2011, at University Research Farm PMAS-Arid Agriculture University, Rawalpindi Pakistan, at $33.6^{\circ} \mathrm{N}$ Latitude and $73^{\circ} \mathrm{E}$ Longitude, to evaluate the relative efficacy of different post-emergence herbicides and their effect on rainfed wheat establishment and growth under semi-arid conditions.

\section{Design}

The experiment was laid out in Randomized Complete Block Design (RCBD) under split plot arrangement with three replications. The individual plot size was $6 \mathrm{~m} \times 3 \mathrm{~m}$ comprising thirteen crop rows $22.5 \mathrm{~cm}$ apart. The fertilizers NPK were applied at the time of seedbed preparation @ 90-60-60 kg ha-1 as a recommended dose. Wheat variety Chakwal-50 was sown with rabi sowing drill during the $1^{\text {st }}$ fortnight of October 2010 at a recommended seed rate of $125 \mathrm{Kg} \mathrm{ha}$ ${ }^{1}$. All the cultural practices were followed according to the recommendations except treatments.

\section{Treatments}

The treatments were Weedy check, weed free check, Clean wave 15 EO (Aminopyrald + fluroxypyre) @ $0.8 \mathrm{~L} \mathrm{ha}^{-1}$, Aim 40 DF (Carfentrazone ethyl)@ 0.05 $\mathrm{Kg} \mathrm{ha}{ }^{-1}$, Buctril-super 60 EC (Bromoxynil + MCPA) @ $0.750 \mathrm{~L} \mathrm{ha}^{-1}$, Atlantis 3.6 WG (Mesosulfuron + iodosulfuron)@ $0.7 \mathrm{Kg} \mathrm{ha}^{-1}$, Sectril-M 40 EC (Bromoxynil+ MCPA)@1.2 $\mathrm{L} \mathrm{ha}^{-1}$, Brominal-M 40 EC (Bromoxynil + MCPA)@ $2.0 \mathrm{Kg} \mathrm{ha}^{-1}$. All the herbicides were applied 30 days after sowing of wheat at recommended rates as suggested by concerned companies.

\section{Data collection}

The weeds behavior in response to application of post-emergence herbicides was observed, and data were recorded for weed parameters viz. weed population before and after herbicide application, weeds mortality percentage, weed biomass before and after herbicide application and weeds control efficiency. Besides herbicide efficiency, wheat parameters viz. germination count, number of tillers $/ \mathrm{m}^{2}$, plant height $(\mathrm{cm})$, spike length $(\mathrm{cm})$, biological yield $\left(\mathrm{kg} \mathrm{ha}^{-1}\right)$, grain yield $\left(\mathrm{kg} \mathrm{ha}^{-1}\right)$ and harvest index (\%) were also measured. Weed population was recorded using a quadrate of one square meter, taking two samples from each plot before and after application of treatments and the average was determined. Weed biomass was taken before, and after application of treatments for which weeds were placed in an oven at $65^{\circ} \mathrm{C}$ for 48 hours and dry matter, weight was recorded. Weed control efficiency was calculated using the following formula.

$$
\boldsymbol{W C E}(\%)=\frac{D M W u t-D M W t}{D M W u t} \times 100
$$

Where; DMWut = Dry matter of weeds from un-treated plots; DMWt $=$ Dry matter of weeds from treated plots.

Where; as, weeds mortality percentage was calculated using the following formula:

$$
\text { Mortality (\%) }=\frac{\mathrm{Wt}-\mathrm{WS}}{\mathrm{Wt}} \times 100
$$

Where; $\mathrm{W}_{\mathrm{t}}=$ Total number of weeds; $\mathrm{W}_{\mathrm{s}}=$ Number of surviving weeds.

The spike length of ten randomly selected spikes was recorded in centimeters starting from the base to the end of the spike, but not including awns and then the average was calculated for taking spike length. At maturity each plot was harvested, weighed for biological yield, and after threshing total grain yield per plot was recorded and then divided by total biological yield of the plot to calculate the harvest index by the following formula.

$$
\text { Harvest Index }(\%)=\frac{\text { Total Grain Yield }(\mathrm{kg})}{\text { Biological yield }(\mathrm{kg})} \times 100
$$

\section{Statistical analysis}

The statistical analysis of mean data was done by using the software STATISTIX 8.1. The least signifi- 
cant difference (LSD) test at 0.05 probability levels was applied to compare the difference among treatments means.

\section{Results and Discussion}

\section{Weed density $\left(m^{-2}\right)$}

Weeds were counted before and after the application of herbicides to determine which herbicide was better as compared to others to control a maximum number of broadleaved weeds. The related data are presented in Table 1. The prominent broadleaved weeds found before application of herbicides were Maina (Medicago sativa), Bathu (Chenopodium album), Shahtra (Fumaria indica), Lehli (Convolvulus arvensis), Billi booti (Anagallis arvensis) and Chatri dhohdak (Euphorbia helioscopia). The data indicated that the weeds free check was the best compared to all broad-leaved herbicides applied and weedy check. Among broadleaved herbicides applied clearly indicated that Buctril-super $\left(16 \mathrm{~m}^{-2}\right)$ and brominal-M $\left(19 \mathrm{~m}^{-2}\right)$ proved to be efficient in controlling weed population followed by aim $\left(25 \mathrm{~m}^{-2}\right)$ and sectril-M $\left(29 \mathrm{~m}^{-2}\right)$ while atlantis $\left(43 \mathrm{~m}^{-2}\right)$ and clean wave (33 $\mathrm{m}^{-2}$ ) gave minimum control of broad-leaved weeds under semi-arid conditions. The $76 \%$ decrease in the weed density with applications of Buctril super was reported by Sharif et al. (2005). The results are also in correspondence with the findings of Abbas et al. (2009), Marwat et al. (2008) and Khan et al. (2004).

\section{Weed mortality (\%)}

Data regarding weed mortality percentage in response to different post emergence applied broad-leaved herbicides showed that weed-free check resulted in full control (100 \%) with respect to controlling broadleaved weeds compared to other treatments (Table 1). Among the broadleaved herbicides applied, Brominal-M (64 \%) and Buctril-super (63\%) gave better control in rainfed wheat followed by Aim (47\%) and Sectril-M (43\%) while Atlantis (28\%) and Clean wave $(18 \%)$ gave minimum control of broad-leaved weeds. The results are correlated with the findings of Ashiq et al. (2007), who reported that the weed density significantly decreased through the application of herbicides. The minimum value was recorded for the weedy check $(00.00 \%)$ which was due to no application of herbicides or hand weeding.

\section{Weed dry biomass $\left(\mathrm{gm}^{-2}\right)$}

The weed dry biomass accumulation is an applicable parameter for evaluating the antagonistic nature of weeds for resource utilization and competing with crop plants. All the weed control methods significantly reduced the weed biomas. The data pertaining to weed biomass is presented in Table 1 , which clearly showed that treatments behaved differently with regard to weed biomass. The weedy check produced the highest weed biomass $\left(114.62 \mathrm{gm}^{-2}\right)$ as no weedicide was applied to control weeds in this treatment. The maximum weed biomass after the weedy check was found in Clean wave $\left(6.23 \mathrm{gm}^{-2}\right)$ and Atlantis (6.23 $\left.\mathrm{gm}^{-2}\right)$. The weed-free check had $100 \%$ weed control, so no weed biomass was recorded for it. The rest of the treatments were at par with one another. The data revealed that herbicides were very efficient in suppressing weed biomass compared to weedy check. These findings are in agreement with the results of Abbas et al. (2009), Marwat et al. (2008), Cheema and Akhtar. (2005), Arif et al. (2004) and Khan et al. (2004), who reported that herbicides performed better in controlling weeds than weedy check. The maximum decline in dry weed biomass was attributed to the application of postemergence herbicides. The results are also in agreement with the findings of Zahoor et al., 2012, who reported that the application of Buctril super significantly reduced the weed dry weight. The highest weed biomass of $40.7 \mathrm{~g} \mathrm{~m}^{-2}$ was obtained in the weedy check plots. The results are also in line with the study of Amare et al., 2014, who reported that application of Isoproturon@ $1.00 \mathrm{~kg} \mathrm{ha}^{-1}$ significantly reduced the dry weed weight in wheat.

\section{Weed control efficiency (\%)}

Similarly, all the weed control methods showed a significant difference in the weed control efficiency (WCE) of various tested treatments in wheat ( $\mathrm{Ta}^{-}$ ble 1). The weed control efficiency data indicated that Brominal-M and Buctril-super were found more efficient in controlling broad-leaved weeds compared to other treatments. The highest weed control efficiency of $(98.18 \%)$ was recorded in Buctril super followed by the Brominal-M (98.11\%). Both of the weed control herbicides were statistically similar to each other but extensively differed from the rest of the weed control methods. The herbicides Aim, and Sectril-M also showed better performance in response to weed control efficiency having (97.63 \%) and (97.03\%) values for WCE. The minimum weed control efficiency $(94.56 \%)$ and $(94.56 \%)$ was measured in the Clean wave and Atlantis after weedy check plots. The results are correlated with the study of Hossain et al. (2009), 
Table 1: Weeds parameters as affected by different herbicides.

\begin{tabular}{|c|c|c|c|c|c|c|}
\hline Treatments & $\begin{array}{l}\text { Weeds density } \\
\text { before treat- } \\
\text { ment }\end{array}$ & $\begin{array}{l}\text { Weeds density } \\
\text { after } \\
\text { Treatment }\end{array}$ & $\begin{array}{l}\text { Weeds } \\
\text { Mortality } \\
\text { (\%) }\end{array}$ & $\begin{array}{l}\text { Weeds dry biomass } \\
\text { before treatment }(\mathrm{g} \\
\left.\mathrm{m}^{-2}\right)\end{array}$ & $\begin{array}{l}\text { Weeds dry biomass } \\
\text { after } \\
\text { treatment }\left(\mathrm{g} \mathrm{m}^{-2}\right)\end{array}$ & $\begin{array}{l}\text { Weeds control } \\
\text { efficiency (\%) }\end{array}$ \\
\hline Weedy check & $44.5 \mathrm{~ns}$ & $54.50 " \mathrm{a}$ & --22.47 & $27.00 \mathrm{bc}$ & $114.622^{*}$ & 0.00 \\
\hline Weeds free & 50.5 & $0.00 \mathrm{e}$ & 100.00 & $31.46 \mathrm{~b}$ & $0.00 \mathrm{c}$ & 100.00 \\
\hline Clean wave & 39.5 & $32.50 \mathrm{~b}$ & 17.72 & $28.40 \mathrm{bc}$ & $6.23 \mathrm{~b}$ & 94.56 \\
\hline Aim & 47.5 & $25.25 \mathrm{c}$ & 46.84 & $29.63 \mathrm{bc}$ & $2.72 \mathrm{bc}$ & 97.63 \\
\hline Buctril-super & 43.5 & $16.25 \mathrm{~d}$ & 62.64 & $26.89 \mathrm{bc}$ & $2.09 \mathrm{bc}$ & 98.18 \\
\hline Atlantis & 59.8 & $43.00 \mathrm{a}$ & 28.03 & $27.23 \mathrm{bc}$ & $6.23 \mathrm{~b}$ & 94.56 \\
\hline Sectril-M & 50.0 & $28.50 \mathrm{c}$ & 43.00 & $42.93 \mathrm{a}$ & $3.41 \mathrm{bc}$ & 97.03 \\
\hline Brominal-M & 52.5 & $19.00 \mathrm{~d}$ & 63.81 & $20.50 \mathrm{c}$ & $2.17 \mathrm{bc}$ & 98.11 \\
\hline
\end{tabular}

Ns: non-significant; "Any two means in a column not sharing a letter in common differ significantly at $5 \%$ probability level.

who documented that application of postemergence herbicides reduced the dry weed weight and consequently drastically increased weed control efficiency in wheat. The results are also in accordance with the work of Singh et al. (2013), who reported that maximum weed control efficiency was obtained with the use of herbicides in wheat. The results are in also an agreement with the finding of Amare et al. (2014) who reported that application of Isoproturon @ $1.00 \mathrm{~kg} \mathrm{ha} \mathrm{h}^{-1}$ significantly reduced the dry weed biomass, which ultimately increased the weed control efficiency in wheat. The results for herbicide efficacy are also in line with the research conducted by Abbas et al. (2009) and Marwat et al. (2008) in which they concluded that Buctril-super was the most efficient post-emergence herbicide compared to other herbicides used in the experiments.

\section{Number of tillers $\left(\mathrm{m}^{-2}\right)$}

Analysis of the data revealed that different herbicides showed a significant effect on the number of wheat tillers $\mathrm{m}^{-2}$ (Table 2). Comparison of the treatment means revealed that the maximum numbers of tillers $\left(422 \mathrm{~m}^{-2}\right)$ were recorded with the application of Buctril-super followed by Clean wave $\left(407.00 \mathrm{~m}^{-2}\right)$ and Sectril-M (381.00 $\left.\mathrm{m}^{-2}\right)$. Remaining treatments produced an almost similar number of tillers. The minimum number of tillers $\mathrm{m}^{-2}$ was observed against weedy check. Buctril-super suppressed weeds efficiently, so in the absence of weeds the crop plants established well and produced the maximum number of tillers $\mathrm{m}^{-2}$. Malik et al. (2009) reported that number of tillers significantly improved with the control of broadleaved weeds when Buctril-super was applied at recommended doses compared to other herbicides used in this study.

\section{Plant height $(\mathrm{cm})$}

The data pertaining to plant height is presented in $\mathrm{Ta}-$ ble 2. It is evident from the data that there was no significant difference among treatments for plant height as all the treatments were at par with one another except atlantis which gave minimum plant height of $74.27 \mathrm{~cm}$. The results of this study are in correspondence with the findings of Shah et al. (1989) who stated that the expression of growth attributes is more associated with inheritance than herbicidal treatments. The minimum plant height $(74.275 \mathrm{~cm})$ was recorded in case of Atlantis indicating suppressive effect on wheat plants in addition to weeds as well. In the study in hand, Atlantis affected plant height character more apparently in plots where Atlantis was applied. Sherawat et al. (2005) who have reported the similar findings and narrated that Atlantis decreased the plant height when applied at recommended rates.

\section{Spike length (cm)}

Data concerning spike length were analyzed statistically and are presented in Table 2. Maximum spike length $(4.65 \mathrm{~cm})$ obtained with Clean wave application followed by Brominal-M $(4.60 \mathrm{~cm})$ and Buctril-super $(4.52 \mathrm{~cm})$. Increase in spike length may be attributed to minimum crop-weeds competition in treated plots as significant weed mortality rate was observed for Brominal-M (64.15 \%) and Buctril-super (63.64 \%). Abbas et al. (2009) and Marwat et al. (2008) have reported the similar results for Buctril-super. The minimum spike length $(4.00 \mathrm{~cm})$ was recorded against Sectril-M that was at par with Aim $(4.15 \mathrm{~cm})$ and Atlantis $(4.20 \mathrm{~cm})$, which clearly indicated poor weed control compared to the above-mentioned herbicides, so competition for light, $\mathrm{CO}_{2}, \mathrm{O}_{2}$, water, etc. existed and in turn reduced spike length. Similar results have been reported by Borras et al. (2004). 
Table 2: Wheat parameters as affected by different herbicides.

\begin{tabular}{|c|c|c|c|c|c|c|c|c|}
\hline Treatments & $\begin{array}{l}\text { Number of } \\
\text { tillers }\left(m^{-2}\right)\end{array}$ & $\begin{array}{l}\text { Plant height } \\
\text { (cm) }\end{array}$ & $\begin{array}{l}\text { Spike length } \\
\text { (cm) }\end{array}$ & $\begin{array}{l}\text { Number of } \\
\text { grains spike }{ }^{-1}\end{array}$ & $\begin{array}{l}1000 \text { Grain } \\
\text { weight (g) }\end{array}$ & $\begin{array}{l}\text { Biological } \\
\text { yield }\left(\mathrm{tha}^{-1}\right)\end{array}$ & $\begin{array}{l}\text { Grain yield } \\
\left(\mathrm{t} \mathrm{ha}^{-1}\right)\end{array}$ & $\begin{array}{l}\text { Harvest } \\
\text { index (\%) }\end{array}$ \\
\hline Weedy check & 327.50 *e & $87.97^{*} \mathrm{a}$ & 4.25 bcde & $58.00 \mathrm{ab}$ & 35.75 "de & $8.194 \mathrm{~b}$ & $3.0486^{\circ} \mathrm{c}$ & $37.31{ }^{*} \mathrm{ab}$ \\
\hline Weed free check & $351.50 \mathrm{~d}$ & $89.25 \mathrm{a}$ & $4.40 \mathrm{abcd}$ & $57.25 \mathrm{ab}$ & $40.97 \mathrm{a}$ & $9.514 \mathrm{a}$ & $3.4583 \mathrm{a}$ & $36.68 \mathrm{ab}$ \\
\hline Clean wave & $407.00 \mathrm{~b}$ & $91.30 \mathrm{a}$ & $4.65 \mathrm{a}$ & $60.75 \mathrm{a}$ & $39.34 \mathrm{abc}$ & $9.583 \mathrm{a}$ & $3.0833 b c$ & $32.44 \mathrm{~b}$ \\
\hline Aim & $349.50 \mathrm{~d}$ & $90.85 \mathrm{a}$ & $4.15 \mathrm{de}$ & $54.00 \mathrm{abc}$ & $38.17 \mathrm{abcd}$ & $10.417 \mathrm{a}$ & $3.4097 \mathrm{ab}$ & $32.90 \mathrm{~b}$ \\
\hline Buctril-super & $422.25 \mathrm{a}$ & $91.27 \mathrm{a}$ & $4.52 \mathrm{abc}$ & $60.75 \mathrm{a}$ & $39.58 \mathrm{ab}$ & $10.556 \mathrm{a}$ & $3.5694 \mathrm{a}$ & $34.59 \mathrm{~b}$ \\
\hline Atlantis & $339.25 \mathrm{de}$ & $74.27 \mathrm{~b}$ & 4.20 cde & $49.50 \mathrm{bc}$ & $36.29 \mathrm{cde}$ & $5.764 \mathrm{c}$ & $2.4028 \mathrm{~d}$ & $42.18 \mathrm{a}$ \\
\hline Sectril-M & $381.00 \mathrm{c}$ & $91.27 \mathrm{a}$ & $4.00 \mathrm{e}$ & $47.75 \mathrm{c}$ & 37.17 bcde & $10.486 \mathrm{a}$ & $3.2639 \mathrm{abc}$ & $32.20 \mathrm{~b}$ \\
\hline Brominal-M & $340.25 \mathrm{de}$ & 88.90 a & $4.60 \mathrm{ab}$ & $59.75 \mathrm{a}$ & $34.67 \mathrm{e}$ & $10.139 \mathrm{a}$ & $3.4167 \mathrm{ab}$ & $34.58 \mathrm{~b}$ \\
\hline
\end{tabular}

"Any two means in a column not sharing a letter in common differ significantly at $5 \%$ probability level.

Table 3: Cost of production for weedy check plot.

\section{Particulars}

Land preparation

(1) Deep ploughing

(2) Shallow plow and Planking

Seed used

Seed drill

Herbicides application charges

(1) Labor charges

(2) Rent of sprayer

(3) Cost of Herbicide

Chemical fertilizer input
(1) Urea
(2) DAP
(3) SOP

Land rent

\section{Transportation}

(Trolley etc.)

Harvesting

Threshing

Total cost
Unit acre $^{-1}$

$$
\begin{aligned}
& 1 \text { acre }^{-1} \\
& 1 \text { acre }^{-1}
\end{aligned}
$$

$50 \mathrm{Kg}$ acre $^{-1}$

2 labors acre ${ }^{-1}$ day $^{-1}$

1 sprayer acre ${ }^{-1}$

different

1 bag acre
$1 / 2$ bag acre $^{-1}$
$1 / 2$ bag acre $^{-1}$
3000 acre $^{-1}$ year $^{-1}$
2 (trolleys) acre
5 men acre $^{-1}$ day $^{-1}$
2 hrs acre $^{-1}$

1 bag acre ${ }^{-1}$

$1328 \mathrm{bag}^{-1}$

4049 bag $^{-1}$

$1600 \mathrm{bag}^{-1}$

300 person $^{-1}$ day $^{-1}$

400 sprayer $^{-1}$

different

Rs.

Rs. 1328

Rs. 2024.5

Rs. 800

Rs. 3000

1500 Trolly $^{-1}$

Rs. 3000

300 man $^{-1}$ day $^{-1}$

Rs. 1500

$800 \mathrm{hr}^{-1}$

\section{Number of grains spike-1}

The data pertaining to the number of grains spike ${ }^{-1}$ are given in Table 2. The greater number of grains spike $^{-1}$ were recorded in plots treated with Clean Wave (60.75) compared to the rest of the treatments. It was found at par with Buctril-super (60.75) and Brominal-M (59.75). It was probably due to better weed control in treated plots that provided a favorable environment to the crop plants to utilize natural resources efficiently for producing a large number of grains spike ${ }^{-1}$. The Sectril-M produced a smaller number of grains spike ${ }^{-1}$ (47.75) followed by Atlantis (49.50) and Aim (54.00). It was probably be- cause of congenial environment provided for weeds to compete with main crop plants for natural sources which reduced the spike length as well as number of grains spike ${ }^{-1}$. Cheema and Akhtar (2005) observed the similar results and concluded a small number of grains spike ${ }^{-1}$ in plots who received no treatment and resulted in poor weed control.

\section{0-grain weight $(g)$}

The data given in Table 2 showed significant differences among treatments regarding 1000-grain weight (g). Thehighest 1000 -grainweight $(\mathrm{g})(40.9 \mathrm{~g})$ was recorded for weed-free check followed by Buctril-super (39.5 g) 
Table 4: Economic analysis.

\begin{tabular}{lllllllll} 
Particulars & Weedy & \multicolumn{3}{l}{ Weed free Clean Wave Aim } & \multicolumn{2}{c}{ Buctril super Atlantis } & Sectril-M Brominal-M \\
Cost of weed control (Rs. acre ${ }^{-1}$ ) & --- & 1500 & 650 & 400 & 425 & 843 & 750 & 900 \\
Herbicide application charges & ---- & ---- & 1000 & 1000 & 1000 & 1000 & 1000 & 1000 \\
Total cost (Rs. acre ${ }^{-1}$ ) & 18952.5 & 20452.5 & 20602.5 & 20352.5 & 20377.5 & 20795.5 & 20702.5 & 20852.5 \\
Grain yield (Kg acre $\left.{ }^{-1}\right)$ & 1220 & 1382.22 & 1233.33 & 1364.44 & 1426.67 & 960 & 1304.44 & 1366.67 \\
Grain yield value (Rs.) & 28975 & 32827.72 & 29291.59 & 32405.45 & 33883.41 & 22800 & 30980.45 & 32458.41 \\
Straw yield (Kg acre $\left.{ }^{-1}\right)$ & 1895.56 & 2440 & 2600 & 2946.67 & 2795.55 & 1344.44 & 2888.89 & 2688.89 \\
Straw yield value (Rs.) & 11847.25 & 15250 & 16250 & 18416.69 & 17472.19 & 8402.75 & 18055.56 & 16805.56 \\
Gross income (Rs.) & 40822.25 & 48077.72 & 45541.59 & 50822.14 & 51355.6 & 31202.75 & 49036.01 & 49263.97 \\
Net benefit (Rs.) & 21869.75 & 27625.22 & 24939.09 & 30469.64 & 30978.1 & 10407.25 & 28333.51 & 28411.47 \\
Benefit cost ratio & 2.15 & 2.35 & 2.21 & 2.50 & 2.52 & 1.50 & 2.37
\end{tabular}

"Grain yield value: Rs. 950/40Kg; Straw yield value: Rs. 250/40Kg.

and Clean wave $(39.3 \mathrm{~g})$. As both these herbicides provided increased spike length, grains spike ${ }^{-1}$ and grain weight spike ${ }^{-1}$ due to the optimum weed control efficacy. Brominal-M produced minimum 1000-grain weight $(34.6 \mathrm{~g})$ followed by Atlantis $(36.2 \mathrm{~g}$ ) and weedy check $(35.7 \mathrm{~g})$. Atlantis caused plant injury and resulted in reduced plant height and other yield parameters which produced minimum 1000-grain weight. In weedy check, no treatment was applied to control weeds. Therefore they caused significant competition with crop and reduced 1000-grain weight. These findings are in conformity with those of Bibi et al. (2008), Cheema and Akhtar (2005) and Khan et al. (2004), who found that weedy check treatment showed significant crop-weeds competition for natural resources which restricted the crop plants to utilize inputs efficiently, therefore resulted in poor crop production.

\section{Biological yield $\left(\mathrm{kg} \mathrm{ha}^{-1}\right)$}

The data related to biological yield are given in $\mathrm{Ta}^{-}$ ble 2 . The data indicated that all applied treatments provided similar results for biological yield means and were at par with each other except Atlantis that showed the minimum value for biological yield (6.87 $\left.\mathrm{t} \mathrm{ha}^{-1}\right)$ followed by a weedy check $\left(9.30 \mathrm{t} \mathrm{ha}^{-1}\right)$. It was probably due to the poor performance of herbicide to control weeds, so weeds dominance restricted crop plants from the utilization of natural resources effectively and resulted in lower biological yield as compared to other treatments. Abbas et al. (2009), Malik et al. (2009) and Marwat et al. (2008) also observed that herbicides increased biological yield in wheat. Therefore, it is essential to control weeds effectively to harvest maximum possible grain yield of wheat with superior quality (Marwat et al., 2008). Most prevalent broadleaved weeds under rainfed conditions include Bathu (Chenopodium album L.), Leh (Cirsium arvense L.), Lehli (Convolvulus arvensis L.), Shahtra (Fumaria indica), Maini (Trigonella monantha C. A. Meyer), Jangli palak (Rumex dentatus L.), Revari (Vicia tetrasperma L.), etc. (Abbas et al., 2009).

\section{Grain yield $\left(k g h a^{-1}\right)$}

The data related to grain yield are given in Table 2 . The cost of production for untreated wheat crop is mentioned in Table 3. The benefit-cost ratio was also highest (2.52) under Buctril Super treated plot (Table 4). The data of Table 2 indicated that Buctril Super applied plot produced maximum grain yield $(3.56 \mathrm{t}$ ha-1) followed by weed-free check plot $\left(3.45 \mathrm{t} \mathrm{ha}^{-1}\right)$, Brominal-M (3.41 tha-1), Aim (3.40 t ha-1) and Sectril-M (3.26 t ha $\left.\mathrm{a}^{-1}\right)$ which were statistically at par with each other. Grain yield was minimum (2.40 $\left.\mathrm{t} \mathrm{ha}^{-1}\right)$ in the plots where Atlantis was applied followed by a weedy check $\left(3.04 \mathrm{tha}^{-1}\right)$. The lowest cost of production (Rs. 18452.5) was under the weedy check plot (Table 4) whereas the benefit-cost ratio was also minimum (2.15) under the weedy check plot. The minimum grain yield in weedy check and Atlantis applied plots may be probably due to the poor performance of herbicide to control weeds, so weeds dominance restricted crop plants from the utilization of natural resources effectively and resulted in lower grain yield as compared to other treatments. Abbas et al. (2009), Malik et al. (2009) and Marwat et al. (2008) also observed that herbicides increased grain yield in wheat. Therefore, it is essential to control weeds effectively to harvest maximum possible grain yield of wheat with superior quality (Marwat et al., 2008). 
Harvest index (\%)

Data pertaining to harvest index are presented in $\mathrm{Ta}-$ ble 2. It indicated that the maximum value was observed with Atlantis (43.395 \%) which was followed by a weedy check (43.170\%). Rests of the other treatments were at par with each other.

\section{Conclusions and Recommendations}

Buctril-super and Brominal-M proved to be more efficient, productive and economical herbicide in controlling broad-leaved weeds in wheat under rainfed conditions compared to other applied herbicides. Moreover, benefit-cost ratio and grain yield of wheat were highest under Buctril-super treated plots. Therefore, Buctril-super is recommended for best control of broad-leaved weeds and to get an economical yield of wheat.

\section{Acknowledgment}

Cordially thanks to my University and Supervisor Prof. Dr. Muhammad Azim Malik for technical and moral support for successfully conducting and publishing my research work.

\section{Author's Contribution}

Zubina Hameed conducted the field experiment and Muhammad Azim Malik, Safdar Ali, Muhammad Ansar and Ijaz Ahmad provided technical input throughout the experiment and helped in writing the article; whereas, Farina Shaheen and Khisro Kalim helped in data collection and data analysis.

\section{References}

Abbas, S.H., M. Saleem, M. Maqsood, M.Y. Mujahid, M. Hassan and R. Saleem. 2009. Weed density and grain yield of wheat as affected by spatial arrangements and weeding techniques under rainfed conditions of Pothowar. Pak. J. Agric. Science; 46 (4): 242- 247.

Abbas, G., M.A. Ali., Z. Abbas., M. Aslam and M. Makram. 2009. Impact of different herbicides on broadleaf weeds and yield of wheat. Pak. J. Weed Sci. Res. 15(1): 1-10.

Ahmad, K., Z. Shah, I. Khan, M. Khan and M.Q. Khan. 1993. Effect of post-emergence herbicides application and hand weeding on wheat and weed pressure. Pak. J. Weed Sci. Res. 6(1-
2): 40-45.

Akbar, N., K.J. Ehsanullah and M.A. Ali. 2011. Weed management improves yield and quality of direct seeded rice. Aust. J. Crop Sci. 5: 688694.

Amare, T., J.J. Sharma and K. Zewdie. 2014. Effect of weed control methods on weeds and wheat (Triticum aestivum L.) yield. World J. Agric. Res. 2(3): 124-128. https://doi.org/10.12691/ wjar-2-3-7

Arif, M., I.U. Awan and H.U. Khan. 2004. Weed management strategies in wheat (Triticum aestivum L.). Pak. J. Weed Sci. Res. 10(1-2): 11-16.

Ashiq, N.M. and N. Ahmad. 2007. Comparative efficacy of different herbicides against broadleaved weeds in wheat. Pak. J. Weed Sci. Res. 13(3-4): 149-156.

Ashiq, M. and Z.A. Cheema. 2005. Effective Use of Herbicides. Weed Sci. Allelopathy Lab. Univ. Agric. Faisalabad, Pak.

Ashiq, M., N. Muhammad and N. Ahmad. 2007. Comparative efficacy of different herbicides against broadleaf weeds in wheat. Pak. J. Weed Sci. Res., 13(3-4): 149-156.

Bekelle, A. 2004. Assessment and management of weeds in wheat in Debark woreda, North Gonder. Unpublished thesis. Haramaya - Ethiopia.

Bibi, S., K.B. Marwat., G. Hassan and N.M. Khan. 2008. Effect of herbicides and wheat population on control of weeds in wheat. Pak. J. Weed Sci. Res. 14(3-4): 111-119.

Borras, L., G.A. Slafer and M.E. Otegui.2004. Seed dry weight response to source-sink manipulations in wheat, maize and soybean: a quantitative reappraisal. Field Crop Res. 86: 131-146. https://doi.org/10.1016/j.fcr.2003.08.002

Cheema, M.S. and M. Akhtar. 2005. Efficacy of different post emergence herbicides and their application methods in controlling weeds in wheat. Pak. J. Weed Sci. Res. 11(1-2): 23-30.

Fayad, T.B., S.R.S. Sabry and E.S.H. Aboul. 1998. Effect of herbicides on weed density, wheat grain yield, and yield components. Stuttgart-Hohenheim, Germany, Conf. Weed Biol. Control.

GoP. 2010. Agric. Statistics of Pakistan. Ministry of Food and Agri. (Economic wing). Islamabad.

Haleemi, 1994. Survey of Weed flora of Wheat in Faisalabad Division. Proc. 4th All Pakistan Weed Science Conference Mar 26-27, Univ. Agric., Faisalabad, Pak. 
Haq, A. 1970. Losses caused by crop pests in Pakistan. J. Agric. Res. Punjab. 8(3): 297-303.

Hossain, M.I., M.E. Haque, K.D. Sayre, R.K. Gupta, S.N. Talukder and M.S. Islam. 2009. Herbicidal effect on the growth and yield of wheat. Int. J. Sustainable Crop Prod. 4(5): 1-4.

Jabran, K., Z.A. Cheema, M. Farooq, S.M.A. Basra, M. Hussain and H. Rehman 2008. Tank mixing of allelopathic crop water extracts with pendimethalin helps in the management of weeds in canola (Brassica napus L.) field. Int. J. Agric. Biol. 10: 293-296.

Khalil, M.F., G. Hassan., G. Ahmad and N.H. Shah. 2008. Individual and combined effect of different herbicides on weed control in wheat. Pak. J. Weed Sci. Res. 14(3-4): 131-139.

Khan, I., G. Hassan., M.I. Khan and I.A. Khan. 2004. Efficacy of some new herbicidal molecules on grassy and broadleaf weeds in wheat. Pak. J. Weed Sci. Res. 10(1-2): 33-38.

Majid, A. and M.R. Hussain. 1983. Studies on chemical weed control in wheat. J. Agric. Res. 21(4): $17-171$.

Malik, A.U., I. Hussain, M.A. Alias, H.A. Bakhsh, M.A. Haji and M. Ali. 2009. Demonstration and evaluation of effect of weedicides on broad leaved weeds on wheat yield. J. Anim. Plant Sci. 19(4): 193-196.

Marwat, K.B., M. Saeed, Z. Hussain, B. Gull and H. Rashid. 2008. Study of various herbicides for weed control in wheat control in wheat under irrigated conditions. Pak. J. Weed Sci. Res. 14(1-20): $1-8$

Prasad, K. and R.S. Singh. 1995. Influence of weed and nitrogen management on weed growth, nutrient uptake and yield of wheat (Triticum aestivum). India. J. Agric. Sci. 65(2): 117-122.
Rao, V.S. 1983. Principles of Weed Science. Oxf. publishing Co. New Delhi. pp. 540.

Razzaq, A., Z.A. Cheema, K. Jabran, M. Farooq, A. Khaliq and G. Haider. 2010. Weed management in wheat through combination of allelopathic water extracts with reduced doses of herbicides. Pak. J. Weed Sci. Res. 16: 247-256.

Shah, M.L., A. Jalis, M. Ramzan and M. Iqbal. 1989. Chemical weed control in broad cast sown wheat under irrigated conditions. J. Agric. Res. 27(3): 195-199.

Shahid, I. 1994. Screening of different herbicides for controlling weeds in wheat crop M.Sc. Thesis, Fac. Agric. Gomal Univ. D.I. Khan.

Sharif, M.M., Z.A. Cheema and A. Khaliq. 2005. Reducing herbicide dose in combination with sorghum water extract for weed control in wheat (Triticum aestivum L.). Int. J. Agric. Biol. 7: 560-563.

Sherawat, S.M., M. Inayat and M. Ahmad. 2005. Bio-efficacy of different graminicides and their effect on the growth and yield of wheat crop. Int. J. Agric. Biol. 7(3): 1560-8530.

Singh, R.K., S.R.K. Singh and U.S. Gautam. 2013. Weed Control Efficiency of Herbicides in Irrigated Wheat (Triticum aestivum). India. Res. J. Ext. Edu. 13(1): 126-128.

Zahoor, F., M.A. Malik, K. Mehmood, M. Rasheed, R. Ansar and M. Hussain. 2012. Optimizing herbicide use in wheat (Triticum aestivum) under rain-fed conditions. Afr. J. Agric. Res. 7(35): 4858-4866. https://doi.org/10.5897/ AJAR10.699

Zimdhal, R.L. 1980. Weed-crop competition. A Review. International Plant Protection Center, Oregon State Univ. U.S.A. pp. 196. 